\title{
Discriminating the ancestral progenitors of hexaploid Festuca arundinacea using genomic in situ hybridization
}

\author{
M. W. HUMPHREYS*, H. M. THOMAS, W. G. MORGAN, M. R. MEREDITH, J. A. \\ HARPER, H. THOMAS, Z. ZWIERZYKOWSKI† \& M. GHESQUIÉRE † \\ Institute of Grassland and Environmental Research, Plas Gogerddan, Aberystwyth, Wales, SY23 3EB, U.K., †Polish \\ Academy of Sciences, Institute of Plant Genetics, 60-479 Poznan, ul Strzeszynska 34, Poland and $\ddagger$ INRA Centre Poitou- \\ Charentes, Station d'Amelioration des Plantes Fourrageres, 86600 Lusignan, France
}

\begin{abstract}
The phylogeny of Festuca arundinacea Schreb. $(2 n=6 \mathrm{x}=42)$ was determined using GISH. Total genomic DNA of putative ancestral species was labelled with rhodamine and hybridized to chromosome preparations of hybrids involving these species and $F$. arundinacea. The degree of hybridization to chromosomes known to be homologous to the probe DNA was compared with that found simultaneously on chromosomes of the genome of $F$. arundinacea. It was concluded that the tetraploid species Festuca arundinacea var. glaucescens contributed two genomes and the diploid species Festuca pratensis one, to create the allohexaploid species $F$. arundinacea.
\end{abstract}

Keywords: Festuca arundinacea, Festuca glaucescens, Festuca pratensis, GISH, phylogeny.

\section{Introduction}

Tall fescue (Festuca arundinacea Schreb.) is a hexaploid $(2 n=6 x=42)$, bivalent forming species with a wide range of distribution from North Africa to northern Europe (Borrill et al., 1976). The tetraploid species $F$. arundinacea var. glaucescens Boiss $(2 n=4 x=28)$ (referred to here as $F$. glaucescens) and the diploid $F$. pratensis Huds. $(2 n=2 \mathrm{x}=14)$ were proposed as two of the progenitors of $F$. arundinacea by Chandrasekharan \& Thomas (1971). They based their conclusions on the evidence of close morphological similarities between the $F_{1}$ hybrid $F$. glaucescens $\times F$. pratensis and tall fescue, together with data on the meiotic behaviour of hybrids and derivatives. Several authors considered that $F$. pratensis was the source of the A genome of $F$. glaucescens (Malik \& Thomas, 1967; Chandrasekharan \& Thomas, 1971). Others agreed that $F$. pratensis was one genome in hexaploid $F$. arundinacea but that it and $F$. glaucescens were separate genomes and together led to the formation of the hexaploid species (Sleper \& Nelson, 1990; Humphreys \& Ghesquière, 1994; Xu \& Sleper, 1994).

The precise nature of differentiation at the molecular level between chromosomes of species within the Lolium/Festuca complex can be revealed through the use of in situ hybridization techniques (Thomas et al.,

*Correspondence.
1994); the chromosomes of different species can be identified by using genomic DNA probes together with excess quantities of DNA of the other species as blocker. In this report we describe a series of in situ hybridization studies involving three hybrids between $F$. pratensis, $F$. glaucescens and $F$. arundinacea to confirm the phylogeny of the hexaploid species.

\section{Materials and methods}

The hybrids $F$. pratensis $\times F$. glaucescens and $F$. pratensis $\times F$. arundinacea were produced by pollinating synthetic autotetraploid cytotypes $(2 n=4 \mathrm{x}=28)$ of $F$. pratensis with the other two species. A hexaploid hybrid combining the two haploid genomes of $F$. glaucescens, one genome of $L$. multiflorum and the three genomes of $F$. arundinacea was produced by doubling the chromosome number of the $F_{1}$ hybrid $L$. multiflorum $(2 \mathrm{x}) \times F$. glaucescens $(4 \mathrm{x})$ and pollinating the amphiploid with $F$. arundinacea $(6 \mathrm{x})$. The hybrids therefore had the following proposed genomic constitutions.
(1) F. pratensis $(\mathrm{P}) \times F$. glaucescens $(\mathrm{G})(4 \mathrm{x})-\mathrm{PPGG}$;
(2) F.pratensis $(\mathrm{P}) \times$
F. arundinacea $(\mathrm{PG})(5 \mathrm{x})-\mathrm{PPPGG}$
(3) L. multiflorum $(\mathrm{M}) \times F$. glaucescens $(\mathrm{G}) \times$
F. arundinacea $(\mathrm{PG})(6 \mathrm{x})-\mathrm{MPGGGG}$. 
All hybrids required embryo rescue. Mitoses from root tip meristems were used as substrate for in situ hybridization with total genomic DNA probe (TGP) from $F$. pratensis and $F$. glaucescens.

The methods of root tip preparations, DNA extraction and labelling, and in situ hybridization were as described by Thomas et al. (1994). All of the TGPs were labelled with rhodamine-4-dUTP (Fluoro-red, Amersham) after first being sheared to 200 to 1000 base pairs by suspending a microfuge tube containing the DNA in an ultrasonic bath for 6 min. All preparations were counterstained with DAPI and mounted in Vectashield antifade. They were examined using a Leitz DM microscope. DAPI and rhodamine images were photographed and superimposed on Kodak Ektachrome $400 \mathrm{HC}$ slide film.

\section{Results}

\section{F. pratensis $(4 x) \times F$. glaucescens $(4 x)$}

The tetraploid hybrid contains two homologous sets of $F$. pratensis chromosomes and the two genomes of $F$. glaucescens. The hybrid was probed with $F$. pratensis TGP: 14 chromosomes fluoresced and 14 were dull with minimal cross hybridization (Fig. 1a). This result shows that the $F$. pratensis genome is not present in $F$. glaucescens.

\section{F. pratensis $(4 x) \times F$. arundinacea $(6 x)$}

On the assumption that there is close affinity between $F$. pratensis and one of the genomes of $F$. arundinacea, the $F$. pratensis TGP would be expected to hybridize to 21 chromosomes of the hybrid. As can be seen in Fig. $1 b, 21$ chromosomes do fluoresce confirming that $F$. pratensis is one of the progenitors of the hexaploid species since the third set of 7 chromosomes that fluoresce has to be one of the $F$. arundinacea genomes.

\section{(L. multiflorum $\times F$. glaucescens) $(6 x) \times F$. arundinacea $(6 x)$}

This hybrid contains the three genomes of $F$. arundinacea, the two genomes of $F$. glaucescens and one genome of $L$. multiflorum. When the $F$. glaucescens TGP was used with $L$. multiflorum and $F$. pratensis DNA as blocker, 28 chromosomes fluoresced red and 14 chromosomes remained dull. $F$. glaucescens DNA has therefore hybridized to the $F$. glaucescens genomes and to two of those from $F$. arundinacea. This is evidence that two of the $F$. arundinacea genomes are homologous to those of $F$. glaucescens.
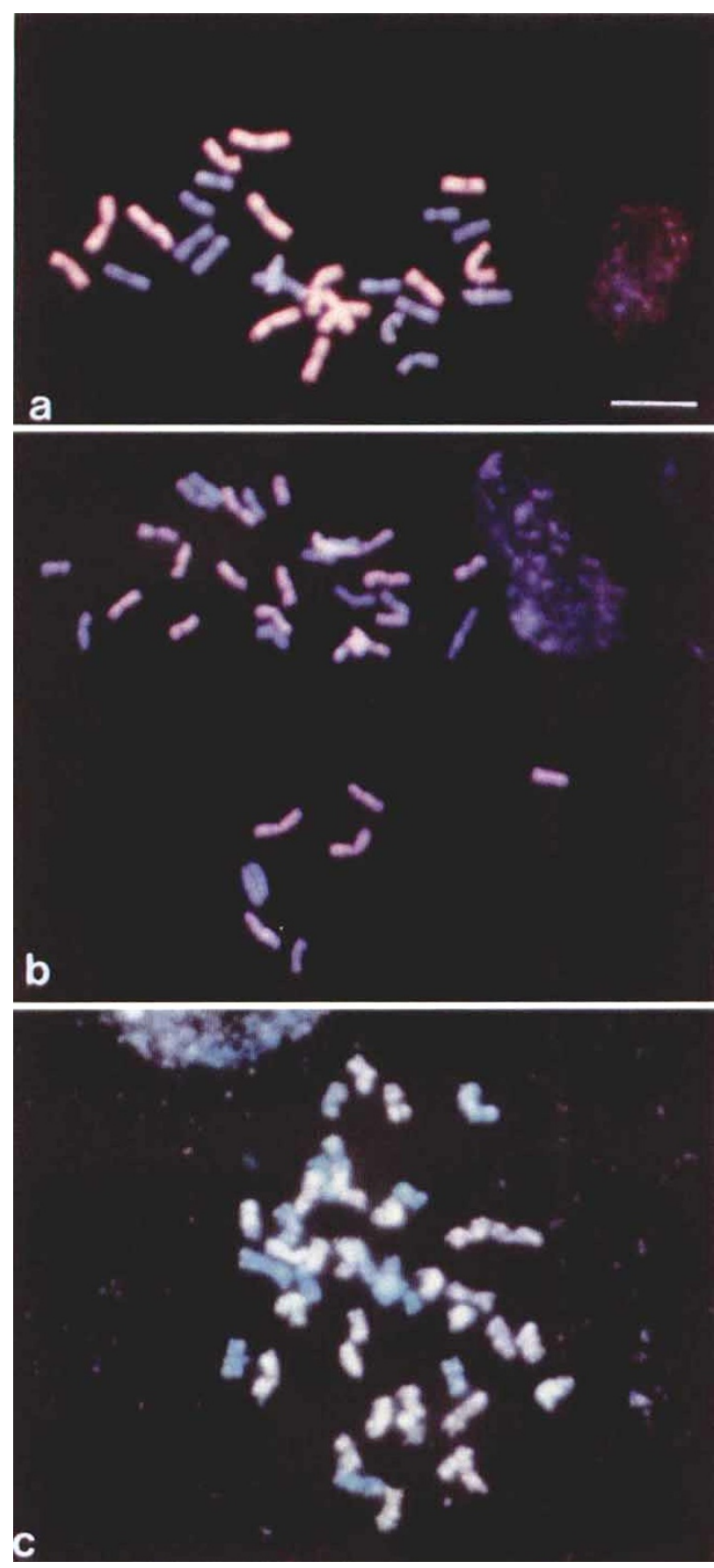

Fig. 1 Genomic in situ hybridization of root tip chromosomes of (a) Festuca pratensis $(4 \mathrm{x}) \times F$. glaucescens $(4 \mathrm{x}),(\mathrm{b}) \mathrm{F}$. pratensis $(4 \mathrm{x}) \times F$. arundinacea $(6 \mathrm{x}),(\mathrm{c})$ (Lolium multiflorum $\times F$. glaucescens $)(6 x) \times F$. arundinacea $(6 x)$. Bar $=10 \mu \mathrm{m}$.

\section{Discussion}

The evidence obtained in this study of phylogenetic relationships based on in situ hybridization confirms previous conclusions that the hexaploid species

(c) The Genetical Society of Great Britain, Heredity, 75, 171-174. 
evolved from a hybrid involving $F$. glaucescens and $F$. pratensis (Chandrasekharan \& Thomas, 1971; Sleper \& Nelson, 1990). Total genomic probes can be used to distinguish between chromosomes of different species within the Lolium/Festuca complex, relying on speciesspecific repetitive DNA sequences. Perez-Vicente $e t$ al. (1992) isolated species-specific DNA sequences from $L$. multiflorum and $F$. arundinacea. Some similarities were found between $F$. arundinacea and $F$. pratensis but these similarities did not extend to L. multiflorum. The precise comparison based on the structure of DNA therefore rules out the involvement of the ryegrass genome in the evolution of tall fescue.

The results of the in situ hybridization confirm the conclusions of the earlier reports that $F$. arundinacea is derived from a hybrid between the diploid species $F$. pratensis and the tetraploid $F$. glaucescens. Any uncertainty whether $F$. pratensis had contributed a genome to $F$. glaucescens was resolved; the hybridization of $F$. pratensis TGP only to the $F$. pratensis and not the $F$. glaucescens chromosomes in the tetraploid hybrid between the two species was unequivocal proof that $F$. pratensis was not a progenitor of $F$. glaucescens.

A large proportion of the genome of higher plants consists of repetitive DNA and the mechanism by which this DNA has accumulated, i.e. by cycles of mutations and amplifications, seems to have ensured that much of this DNA is species-specific (Flavell et al. 1980). Genomic in situ hybridization relies on the specificity of the repetitive DNA and appears to be very effective in making comparisons between the related genomes of the Lolium/Festuca complex. The substrate for the GISH in each case was a mitotic preparation of a $F_{1}$ hybrid that involved the species used as probe. This provided an internal control because a known number of chromosomes were fully homologous with the probe. It enabled a direct comparison to be made between the degree of hybridization to the chromosomes of the present day putative progenitors and those of the hexaploid. In some cells there appeared to be some differentiation, that is, the signal was brighter on some chromosomes than others. This may indicate changes to the DNA of $F$. arundinacea subsequent to the formation of the initial hybrid, or that the accessions of $F$. pratensis and $F$. glaucescens used were not fully homologous with the genotype of the progenitors.

Cytogenetic analysis based on predictive mathematical formulae to quantify relationships between genomes of different species had indicated that the ryegrass genome was more closely related to one of the tall fescue genomes than the other two (Kleijer, 1984). This was also demonstrated by Humphreys \& Ghesquière (1994) who set up pentaploid hybrids of $L$. multi- florum $(4 \mathrm{x}) \times F$. arundinacea in which different alleles at the PGI/2 locus marked the two homologous chromosomes of ryegrass and the three homologous tall fescue chromosomes. They were able to show that one of the fescue alleles recombined at a greater frequency than the other two in backcrosses to a diploid L. multiflorum. In view of the data presented in this paper it would be reasonable to assume that this would be the allele marking the genome derived from F. pratensis.

The distribution of fescue species has been recorded by Borrill et al. (1976) who found that the tetraploid species $F$. glaucescens is confined mainly to the southern European mountains and probably extends to central and eastern Europe. The diploid species $F$. pratensis is distributed throughout the climatic regions of oceanic north-west Europe and the transitional oceanic/continental zone of central Europe. $F$. arundinace $a$ is as ubiquitous as the diploid $F$. pratensis except that it is less common in the colder winter conditions of northern Europe and the drier regions of northern Italy. $F$. pratensis is also more prevalent at higher altitudes than $F$. arundinacea. The comparison of the distribution of the three fescue species is interesting, because the tetraploid species is restricted and probably adapted to the conditions in those specific regions, but with the acquisition of the $F$. pratensis genome it became more adaptable as the hexaploid species and was able to spread throughout most of the regions occupied by $F$. pratensis. This is very similar to the effect of the D genome in the evolution of bread wheat (Zohary \& Feldman, 1962). The distribution of the relevant species would also indicate that central Europe is the probable region where $F$. arundinacea evolved as a product of the natural hybridization of the $2 \mathrm{x}$ and $4 \mathrm{x}$ species; this conclusion would be in accord with the designation of this region as the centre of diversity of temperate grass species (Hartley \& Williams, 1956; Borrill, 1972).

\section{References}

BORRILL, M. 1972. Studies in Festuca III. The contribution of $F$. scariosa to the evolution of polyploids in sections Bovinae and Scariosae. New Phytol., 71, 523-532.

BORRILL, M., TYLER, B. F. AND MORGAN, W. G. 1976. Studies in Festuca VII. Chromosome atlas (Part 2). An appraisal of chromosome race distribution and ecology, including $F$. pratensis var. apennina (De Not.) Hack, - tetraploid. Cytologia, 41, 219-236.

ChandRasekharan, P. AND ThOMAs, H. 1971. Studies in Festuca V. Cytogenetic relationships between species of bovinae and scariosae. Z. PflZücht., 65, 345-354.

HARTLEY, W. AND WILLIAMS, R. J. 1956. Centres of distribution of cultivated pasture grasses and their significance for plant 
introduction. Proc. 7th. Int. Grassl. Congr., Palmerston North, New Zealand, pp. 190-201.

HUMPHREYS, M. W. AND GHESQUIËRE, M. 1994. Assessing success in gene transfer between Lolium multiflorum and Festuca arundinacea. Euphytica, 77, 283-289.

FLAVELL, R., RINPAU, J., SMITH, D. B. , O'DELL, M. AND BEDBROOK, J. R. 1980. The evolution of plant genome structure. In: Leaver, C. J. (ed) Genome Organization and Expression in Plants, pp. 35-47. Plenum Press, New York.

KLEIJER, G. 1984. Cytogenetic studies of crosses between Lolium multiflorum Lam. and Festuca arundinacea Schreb. Z. PflZücht., 93, 1-22.

MALIK, C. P. AND THOMAS, P. T. 1967. Cytological relationships and genome structure of some Festuca species. Caryologia, 20, 1-39.

PEREZ-VICENTE, R., PETRIS, L., OSUSKY, M., POTRYKIS, I. AND SPANGENBERG, G. 1992. Molecular and cytogenetic characterization of repetitive DNA sequences from
Lolium and Festuca: applications in the analysis of Festulolium hybrids. Theor. Appl. Genet., 84, 145-154.

SLEPER, D. A. AND NELSON C. J. 1990. Breeding and genetics: potential use of haploids and doubled haploids. In: Kasperbuer, M. J. (ed.) Biotechnology in Tall Fescue Improvement, pp. 167-191. CRC Press, Boca Raton, FL.

THOMAS, H. M., MORGAN, W. G., MEREDITH, M. R., HUMPHREYS, M. W., THOMAS, H. AND LEGGETT, J. M. 1994. Identification of parental and recombined chromosomes in hybrid derivatives of Lolium multiflorum $\times$ Festuca pratensis by genomic in situ hybridization. Theor. Appl. Genet., 88, 909-913.

XU, W. W., AND SLEPER, D. A. 1994. Phylogeny of tall fescue and related species using RFLPs. Theor. Appl. Genet., 88, 685-690.

ZOHARY, D. AND FELDMAN, M. 1962. Hybridization between amphiploids and the evolution of polyploids in the wheat (Aegilops-Triticum) group. Evolution, 16, 44-61. 